Jurnal Pendidikan dan Pemberdayaan Masyarakat
Volume 3 - Nomor 2, November 2016, (109-121)

\title{
PEMBERDAYAAN KOPERASI PONDOK PESANTREN SEBAGAI PENDIDIKAN SOSIAL DAN EKONOMI SANTRI
}

\author{
Adhi Iman Sulaiman ${ }^{1 *}$, M. Masrukin ${ }^{2}$, C. Chusmeru ${ }^{3}$, Sri Pangestuti ${ }^{4}$ \\ ${ }^{1234}$ Fakultas Ilmu Spsial dan Politik, Universitas Jenderal Soedirman. Jalan HR Boenyamin \\ No.708, Grendeng, Purwokerto Utara, Kabupaten Banyumas, Jawa Tengah 53122, Indonesia \\ * Korespondensi Penulis. Email: adhi.2005unsoed@gmail.com
}

\begin{abstract}
Abstrak
Penelitian memiliki tujuan untuk menganalisis pemberdayaan Koperasi Pondok Pesantren (Kopontren) sebagai pendidikan sosial dan ekonomi santri. Penelitian menggunakan metode Participatory Learning and Action (PLA), pengumpulan data melalui, wawancara, pengamatan langsung, Focus Group Discussion (FGD) dan dokumentasi. Pemilihan informan secara purposive sampling yaitu ketua, pengurus dan anggota Kopontren. Lokasi penelitian di Yayasan Pendidikan Agama Islam (YPAI) Pondok Pesantren Darussalam Dukuh Waluh, Banyumas dan El Bayan 1 Majenang, Cilacap. Penelitian menggunakan analisis interaktif. Hasil penelitian menunjukan (1) Pengurus Kopontren memiliki tekad dan semangat yang tinggi untuk membenahi kepengurusan, keanggotaan dan mengembangkan unit usaha sebagai pendidikan sosial serta ekonomi bagi kemandirian santri. (2) Kopontren membutuhkan dukungan dari pimpinan pondok pesantren dan partisipasi semua santri untuk menjadi anggota dan kader Kopontren. (3) Kopontren membutuhkan program pemberdayaan seperti penyuluhan, pelatihan dan pendampingan tentang manajemen kelembagaan, kepengurusan, keanggotaan dan keuangan.
\end{abstract}

Kata Kunci: kemandirian, koperasi, pemberdayaan, pendidikan, pesantren, santri

\section{EMPOWERMENT OF COOPERATIVE BOARDING SCHOOL AS A SOCIAL AND ECONOMIC EDUCATION FOR STUDENT}

\begin{abstract}
The research aim to analysis empowerment program of Cooperative Boarding Schools (Kopontren) as social and economic education of students. The study used Participatory Learning and Action (PLA), data was collected through interviews, observation, Focus Group Discussion (FGD), and documentation. The informants used purposive sampling that chief, committee and members of Kopontren. The research site in Islamic Education Foundation (YPAI) Darussalam boarding school in Dukuh Waluh, Banyumas and El Bayan 1 boarding school in Majenang, Cilacap. The research used interactive analysis. The results showed (1) Cooperative management have the determination and strong spirit to reorganize management, membership and develop the business unit as a social and economic education for independence students. (2) Kopontren have require the support of leaders boarding school and participation of all students to become members and cadres Kopontren. (3) Kopontren have requires empowerment programs such as extension, training and assistance of the institutional management, membership and finances.
\end{abstract}

Keywords: boarding schools, cooperative, education, empowerment, independence, student

How to Cite: Sulaiman, A., Masrukin, M., Chusmeru, C., \& Pangestuti, S. (2016). Pemberdayaan koperasi pondok pesantren sebagai pendidikan sosial dan ekonomi santri. Jurnal Pendidikan dan Pemberdayaan Masyarakat, 3(2), 109-121. doi:http://dx.doi.org/10.21831/jppm.v3i2.11303

Permalink/DOI: http://dx.doi.org/10.21831/jppm.v3i2.11303 


\section{Jurnal Pendidikan dan Pemberdayaan Masyarakat, 3 (2), November 2016 - 110 \\ Adhi Iman Sulaiman, M. Masrukin, C. Chusmeru, Sri Pangestuti}

\section{PENDAHULUAN}

Pesantren adalah lembaga sosial dan pendidikan Islam yang melaksanakan konsep keseimbangan antara kehidupan sebagai bentuk ibadah baik yang bersifat langsung (Mahdhoh) kepada pencipta (Kholiq) yaitu Alloh SWT sebagai kesejahteraan lahir dan ibadah tidak langsung (Ghoir Mahdhoh) dengan berinteraksi secara sosial dan ekonomi untuk mendapat kesejahteraan lahir.

Pendidikan pesantren menjadi sesuatu yang wajib masuk dalam setiap kajian perkembangan pendidikan. Bagaimanapun pendidikan pesantren adalah pendidikan tertua yang pernah ada di Indonesia dan dianggap sebagai produk budaya Indonesia yang indigeneous (Muttaqin, 2014, p.67)

Pesantren dengan memiliki konsep keseimbangan pendidikan moral (batin) dan sosial serta ekonomi (lahir) merupakan filosofi bahwa Islam sebagai rahmat bagi seluruh alam (Rahmatan Lil'aalamiin). Pesantren bukan sebagai lembaga atau komunitas pendidikan yang mendapat stigma negatif seperti tempat penitipan anak-anak yang sudah tidak dapat ditanggulangi keluarga baik dari segi moral, spiritual dan ekonomi serta stigma negatif yang disebut sebagai "sarang teroris".

Menurut hasil penelitian Pusat Penelitian dan Pengembangan (Puslitbang) Pendidikan Agama dan Keagamaan Kementerian Agama RI (2005) bahwa globalisasi memberikan warna terhadap dunia pondok pesantren yang disebabkan oleh adanya kecenderungan global cooptation atau dunia internasional melakukan marjinalisasi, yang pada akhirnya dunia pesantren dihadapkan pada pilihan-pilihan baik bersikap reaktif atau berperan aktif. Sikap reaktif menghasilkan stigma negatif di kalangan dunia internasional seperti pondok pesantren dinilai radikal, konservatif bahkan sebagai sarang teroris.

Pesantren menjadi pendidikan alternatif dan bukan pilihan utama, tetapi memiliki potensi yang mampu bangkit menepis stigma negatif dengan keinginan yang kuat, kemampuan, dan bekerja sama dengan masyarakat melakukan program pemberdayaan yang berhasil membentuk kelompok usaha dan Koperasi Syariah. Menurut Ade (2009, p. 107) ekonomi syariah sebagai solusi alternatif sistem ekonomi yang menjalankan kegiatan ekonomi dengan menjunjung tinggi nilainilai kepemilikan, nilai-nilai keadilan, kebebasan, keseimbangan dan persaudaraan serta kebersamaan. Al-Hamdani (2005, p. 76) menyatakan pesantren merupakan institusi keagamaan yang tidak mungkin bisa dilepaskan dari masyarakat, khususnya masyarakat pedesaan, karena pesantren tumbuh dan berkembang dari dan untuk masyarakat. Daniar (2013, p.215) menegaskan bahwa pondok pesantren memiliki peran yang sangat strategis yaitu sebagai pusat pengembangan agama, pendidikan, sosial dan budaya serta sebagai kekuatan ekonomi.

Dengan demikian pesantren menjadi bagian penting dalam pengembangan lembaga pendidikan baik sosial maupun ekonomi dan agama (moral) yang mampu menjawab tuntutan serta tantangan jaman yang semakin berkembang. Terdapat relevansi pesantren dengan pendidikan nasional termaktub dalam Undang-Undang Nomor 20 tahun 2003 tentang Sistem Pendidikan Nasional, Pasal 3 yaitu Pendidikan nasional berfungsi mengembangkan kemampuan dan membentuk watak serta peradaban bangsa yang bermartabat dalam rangka mencerdaskan kehidupan bangsa, bertujuan untuk berkembangnya potensi peserta didik agar menjadi manusia yang beriman dan bertakwa kepada Tuhan Yang Maha Esa, berakhlak mulia, sehat, berilmu, cakap, kreatif, mandiri, dan menjadi warga negara yang demokratis serta bertanggung jawab.

Berdasarkan tantangan dan tuntutan globalisasi tersebut, maka pesantren memiliki potensi dan kemampuan melakukan pendidikan (1) Pembentukan karakter menjadi insan yang beriman dan bermoral untuk menangkal dampak negatif globalisasi terutama pengaruh negatif teknologi media informasi seperti pornografi yang mengarah pada pornoaksi atau tindakan pelanggaran moral dan hukum. Ubaidillah (2010,p.3) berpendapat bahwa globalisasi dan kebudayaan asing telah masuk dalam masyarakat, dampaknya banyak generasi muda kita yang terjerumus dalam kebudayaan asing yang negatif seperti pergaulan bebas dan lain-lain, 
Jurnal Pendidikan dan Pemberdayaan Masyarakat, 3 (2), November 2016 - 111

Adhi Iman Sulaiman, M. Masrukin, C. Chusmeru, Sri Pangestuti

sehingga peran pesantren dalam membentengi generasi muda kita dari serangan globalisasi masih sangat dibutuhkan.

Pesantren adalah lembaga pendidikan Islam yang tumbuh di masyarakat dengan santri-santrinya mendapatkan sistem asrama (pondok) untuk tinggal, mendapat pendidikan agama melalui pengajian dan madrasah oleh beberapa kiyai atau ulama sebagai pengajar atau pembimbing yang memiliki kepempinan yang kharismatik dan independen (Qomar 2006, p.2). Menurut Peraturan Menteri Agama Republik Indonesia Nomor 18 Tahun 2014 tentang Satuan Pendidikan Muadalah pada Pondok Pesantren bahwa satuan pendidikan muadalah pada pondok pesantren adalah satuan pendidikan keagamaan Islam yang diselenggarakan oleh dan berada di lingkungan pesantren dengan mengembangkan kurikulum sesuai kekhasan pesantren yang islamiyah.

Pengembangan karakter dan keterampilan ekonomi, berjiwa sosial, dan bekerja sama dengan memiliki kegiatan kewirausahaan seperti budi daya perikanan dan peternakan, bengkel motor, warung kelontongan serta Koperasi Pondok Pesantren (Kopontren) sebagai induk usaha untuk kesejahteraan bersama. Sehingga para santri lulusan pesantren dapat menjadi generasi pembangunan yang memiliki karakter bermoral, berwirausaha dan mandiri serta mampu menciptakan lapangan usaha di masyarakat.

Pondok pesantren (Ponpres) telah melakukan berbagai inovasi untuk meningkatkan peran dan sekaligus memberdayakan potensinya bagi kemaslahatan lingkungannya diantaranya mendirikan Koperasi Pondok Pesantren (Kopontren). Kopontren berfungsi sebagai pendukung kehidupan ekonomi Ponpes, sebagai pembinaan kader koperasi pedesaan, dan sebagai stimulator sosio-ekonomi masyarakat desa di sekitar Ponpes (Burhanuddin, 2016, p.1).

Azyumardi (1997, p.1) menjelaskan tumbuhnya gerakan koperasi di kalangan santri merupakan salah satu bentuk perwujudan dari konsep saling menolong (ta'awun), persaudaraan (ukhuwah), menuntut ilmu (tholabul ilmi) dan berbagai aspek ajaran Islam lainnya. Konsep bersama-sama (berjaa'ah) dan dijalankan secara hukum yang jelas dan adil (syariah) yang relevan dengan tujuan koperasi yang didirikan, dikelola syah dengan ketentuan peraturan bersama dan sejahtera untuk anggota secara bersama. Menurut Chotimah (2014, p.133) proses pendidikan kewirausahaan yang dilaksanakan di pondok pesantren dengan melatih santri untuk mengelola lembaga ekonomi supaya selain memiliki bekal ilmu agama yang kuat juga jiwa wirausaha untuk kehidupan. Nadzir (2015, p. 47) menyatakan pesantren memberikan pemberdayaan kepada santri dengan keterampilan atau keahlian dibidang ekonomi seperti koperasi sebagai upaya menempa mental kemandirian.

Lembaga pendidikan pesantren yang memiliki potensi dalam pembangunan karakter dan keterampilan sosial keagamaan dan sosial ekonomi menjadi kajian penting dan menarik khususnya tentang Kopontren. Maka tujuan penelitian yaitu untuk menganalisis pemberdayaan Koperasi Pondok Pesantren (Kopontren) sebagai pendidikan sosial dan ekonomi santri.

\section{METODE}

Penelitian menggunakan metode Participatory Learning and Action (PLA) sebagai salah satu bentuk penelitian kualitatif untuk mengidentifikasi masalah dan potensi masyarakat serta mendapat pemahaman yang mendalam tentang situasi suatu komunitas (perlu referensi). Komunitas adalah subjek penelitian sebagai community worker yang menganalisis dan mengambil keputusan dari permasalahan yang dihadapi. Hal tersebut merupakan assessment, proses belajar, mengoptimalisasikan aspirasi dan partisipasi dari kondisi atau masalah yang dihadapi dari, dengan dan untuk masyarakat (Ade, 2009). Pengumpulan data melalui wawancara, pengamatan langsung, Focus Group Discussion (FGD) dan dokumentasi. Pemilihan informan secara purposive sampling yaitu ketua, pengurus dan anggota Koperasi Pondok Pesantren (Kopontren). Analisis penelitian menggunakan analisis interaktif dari Miles \& Huberman (2007, p. 19-20) yaitu mereduksi, menyajikan data dan verifikasi serta kesimpulan. Lokasi penelitian yang dipilih dengan pertimbangan bahwa Kopontren telah memiliki dan memanfaatkan 


\section{Jurnal Pendidikan dan Pemberdayaan Masyarakat, 3 (2), November 2016 - 112}

Adhi Iman Sulaiman, M. Masrukin, C. Chusmeru, Sri Pangestuti

media teknologi internet sebagai media komunikasi informasi dan promosi, seperti memiliki email, blogspot, website dan alamat facebook, sehingga mudah untuk diakses dan berinteraksi dengan komunitas di luar pesantren, yaitu: (1) Yayasan Pendidikan Agama Islam (YPAI) Pondok Pesantren Darussalam, Jalan Sunan Bonang No 57. RT 03/o6 Dukuh Waluh Kembaran, Kabupaten Banyumas. (2) Yayasan Pendidikan Agama Islam (YPAI) Pondok Pesantren El-Bayan 1 Majenang. Alamat: Jalan Benda Km. o2 Desa Padangjaya Kecamatan Majenang, Kabupaten Cilacap.

\section{HASIL DAN PEMBAHASAN}

\section{Tantangan dan Prospek Pondok Pesantren (Kopontren)}

Pondok pesantren memiliki sejarah sebagai komponen pembangunan bangsa yang membangun karakteristik keagamaan (moral-spiritual), kebangsaan (cinta tanah air) dan ilmu pengetahuan serta keterampilan menuju kemandirian. Kehadiran Koperasi Pondok Pesantren (Kopontren) sebagai mengembangkan kelembagaan (community development) pesantren dan usaha eknomi yang berdasarkan kebersamaan dan pemberdayaan potensi santri serta lingkunganya dalam meraih kesejahteraan dan kemandirian. Menurut Sitio \& Samba (2011) koperasi merupakan kerja sama ekonomi secara sukarela atas nama persamaan hak dan kerjasama melakukan suatu usaha untuk memenuhi kebutuhan para anggota dan masyarat pada umumnya.

Pengembangan komunitas atau community development adalah gerakan yang dirancang untuk meningkatkan kehidupan yang lebih baik melalui partisipasi aktif berupa perencaan dan aksi sosial (Hasim \& Remiswal 2009, p. 50). Community development dapat bersinergi dalam mengembangkan dan memperkuat kelembagaan ekonomi masyarakat yang lebih mensejahterakan dan bisa menjadi model percontohan khususnya bagi pengembangan masyarakat lainnya (Suswanto, Handoko,\& Sabiq 2013, p. 311).

Perinsip Islam dalam tantangan ekonomi yaitu memperjuangkan kesejahteran umum (fala), baik material maupun spiritual dan bisa menjamin keadilan dari motivasi individu, bisnis dan berorganisasi yang harus dibangun berdasarkan kebutuhan, melalui dakwah, keteladanan, pendidikan dan gerakan sosial (Damanhuri 2010, p. 184-185). Menurut Kusmanto (2014, p. 232) sistem ekonomi Islam di perdesaan akan mampu menjadi alternatif dalam memperbaikin kehidupan masyarakat perdesaan yang mayoritas berada dalam jerat kemiskinan. Kemampuan tersebut mengacu pada prinsip dan praktik ekonomi Islam yang mengedepankan keseimbangan kebutuhan individual dan kelompok untuk mencapai kesejahteraan. Widjajanti (2011, p. 15) menegaskan tanggung jawab utama dalam program pembangunan adalah masyarakat berdaya atau memiliki daya, kekuatan atau kemampuan yang dapat dilihat dari aspek fisik dan material, ekonomi, kelembagaan, kerjasama, kekuatan intelektual dan komitmen bersama dalam menerapkan prinsip-prinsip pemberdayaan.

Kajian Kopontren difokuskan pada dua Yayasan Pendidikan Agama Islam (YPAI) yaitu pondok pesantren Darussalam, Dukuh Waluh, Banyumas dan El Bayan 1 Majenang, Cilacap sebagai lembaga pendidikan yang memberikan perhatian selain pada bidang agama, juga pada pemberdayaan sosial dan ekonomi santri.

Pertama, Pondok pesantren Darussalam dirintis oleh KH. Drs. Chariri Shofa, M. Ag. dan H. Djoko Sudantoko, S.Sos., M.M. (mantan Bupati Banyumas) pada bulan Dzulhijjah $1415 \mathrm{H}$ bertepatan dengan bulan Mei 1994 M dan terus mengalami proses pengembangan sampai tahun 1996 dan terdaftar secara resmi tahun 1997. Pendidikan model salafi dalam bentuk klasikal, nonklasikal, sorogan, dan bandungan. Visi Pondok Pesantren Darussalam yaitu terwujudnya kader muslim yang shalih, berakidah yang kuat, konsisten menjalankan syari'at Islam, berakhlak mulia, memiliki kedalaman ilmu dan berwawasan luas serta memiliki keterampilan yang memadai. Misi pondok pesantren Darussalam diantaranya (1) Mewujudkan insan muslim yang memiliki kedalaman ilmu dan keluasan wawasan, taat mengamalkan, mengembangkan dan menyebarluaskan dalam kehidupannya sehari-hari. 


\section{Jurnal Pendidikan dan Pemberdayaan Masyarakat, 3 (2), November 2016 - 113}

Adhi Iman Sulaiman, M. Masrukin, C. Chusmeru, Sri Pangestuti

(2) Menyiapkan calon pemimpin yang memiliki keterampilan yang memadai seiring dengan perkembangan ilmu pengetahuan dan teknologi.

Koperasi Pondok Pesantren (Kopontren) Darussalam awal mulanya dari kelompok santri yang menang lomba kreativitas dan kewirausahaan di pondok pesantren Darussalam pada tahun 2010-2011. Kelompok santri tersebut kemudian dilakukan pembinaan oleh ustadz untuk memiliki jiwa dan semangat kewirausahaan. Awalnya tahun 2011-2012 dirintis usaha sebuah warung yang diberi nama D'Mart singkatan dari Darussalam Mart yang menyediakan kebutuhan sehari-hari santri. Pengelolaan usaha D'Mart sebagai Kopontren sepenuhnya diamanahkan dari pimpinan pondok pesantren yang memberikan modal awal kepada santri sebagai pengurus.

Kelompok usaha D'Mart mendeklarasikan sebagai koperasi pondok pesantren (Kopontren) dengan semangat dan usaha bersama yang masih memiliki tantangan yaitu kopontren belum berbadan hukum dikarenakan pengelolaan D'Mart belum di dukung oleh manajemen perkoperasian secara lengkap seperti kepengurusan, keanggotaan, iuran dan pengelolaan keuangan, pengembangan unit usaha, serta rapat kepengurusan dan anggota. Sehingga Kopontren yang berupa warung D'Mart dikelola berdasarkan semangat, keikhlasan, kepercayaan dan amanah dari pimpinan pondok pesantren untuk menjadi pengurus khususnya kepada santri putri dengan jumlah dua sampai empat orang.

Keterlibatan santri putra dalam kepengurusan D'Mart masih terbatas partisipasinya, rapat pengurus, dan proses jual beli juga kurang intensif, dikarenakan lokasi Kopontren atau D'Mart berada di wilayah pondok santri putri. Santri putra dan putri dengan jumlah sekitar 400 orang belum dilibatkan dalam kepengurusan dan keanggotaan secara resmi tercatat dalam Kopontren. Sehingga permodalan masih mengandalkan iuran dari pengurus.

Kopontren D'Mart masih menjalankan usaha warung klontongan yang menyediakan kebutuhan harian santri dan belum mengembangkan unit usaha lainnya. Santri sebagai pangsa pasar potensial kurang memiliki ikatan kuat untuk memperkuat kelembagaan Kopontren karena belum dilibatkan secara resmi menjadi keanggotaan yang memiliki hak dan kewajiban. Santri masih banyak yang belanja untuk memenuhi kebutuhan harian di luar pondok pesantren atau Kopontren sambil berangkat untuk kuliah dan sekedar ijin ketika waktu rehat atau istirahat. Akses yang mudah dan dekat dari pondok pesantren ke pasar, warung, mini market dan super market menjadikan D'Mart sebagai alternatif belanja bukan tujuan utama.

Pengurus dan anggota Kopontren belum mendapat sosialisasi, penyuluhan dan pendampingan tentang perkoperasian dan unit usaha lainnya. D'Mart sebagai Kopontren Darussalam memiliki potensi besar untuk dikembangkan baik dari segi manajemen kepengurusan, keanggoataan, unit usaha, dan lingkungan yang strategis

Pengurus yang diamanahi oleh pimpinan pondok pesantren memiliki tekad dan semangat yang kuat untuk mengelola D'Mart menjadi Kopontren yang profesional, dapat menjadi pelatihan berwirausaha, menyediakan kebutuhan santri dan pesantren serta mensejahterakan.

Santri berjumlah sekitar 400 orang menjadi sumber daya yang potensial baik untuk menjadi kader pengurus, kelompok usaha, maupun menjadi anggota Kopontren yang akan memperkuat kelembagaan, pengembangan usaha, transaksi jual beli dan permodalan dengan simpanan pokok, simpanan wajib serta simpanan sukarela.

Lokasi dan lingkungan pondok pesantren Darussalam sangat strategis yaitu lahan pekarangan, kebun dan sawah yang ada di sekitar pondok pesantren cukup luas dengan dukungan pengairan yang bagus dari aliran sungai. Sehingga potensial untuk melakukan budi daya peternakan ikan seperti ikan lele, gurame dan nila, kemudian ternak ayam dan itik, kemudian perkebunan dengan komoditas sayuran. Produktifitas dan hasil budi daya bisa dimanfaatkan oleh pondok pesantren atau dapat juga dijual secara komersial dengan skala besar untuk kebutuhan pasar dan rumah makan dengan akses yang dekat serta mudah dari pesantren. Mengembang- 


\section{Jurnal Pendidikan dan Pemberdayaan Masyarakat, 3 (2), November 2016 - 114}

Adhi Iman Sulaiman, M. Masrukin, C. Chusmeru, Sri Pangestuti

kan dapur umum menjadi warung makan dan catering untuk menyediakan kebutuhan makanan harian bagi santri di pondok pesantren.

Para pengurus Kopontren memiliki kesadaran bahwa berwirausaha sebagai pendidikan dan pengalaman penting untuk menjadi bekal setelah lulus. Sehingga memiliki semangat untuk mendapat program pemberdayaan yaitu penyuluhan dan pelatihan tentang manajemen perkoperasian seperti pengelolaan pengurus, keanggotaan, modal atau keuangan, pengembangan usaha dan proses status Kopontren untuk memiliki badan hukum. Penyuluhan dan pelatihan pengembangan unit usaha seperti membuka jasa pencucian (laundry) bagi santri di pondok pesantren, pelayanan jasa rental komputer, cetak (print), photocopy dan media internet sebagai penyediaan kebutuhan santri yang kebanyakan sebagai mahasiswa untuk mendukung proses penyelesaian tugas perkualiahan. Pemberdayaan bidang peternakan seprti budi daya ikan dan ternak ayam serta bebek yang relevan dengan latar belakang santri yang banyak menjadi mahasiswa khususnya jurusan peternakan, perikanan dan pertenaian.

Lokasi pesantren yang memiliki akses dekat dan mudah ke perkotaan, pusat pembelanjaan, dan kampus satu sisi menjadi pangsa pasar potensial untuk pemasaran produk hasil usaha, namun pada sisi lain menjadi tantangan besar karena kebutuhan santri dapat terpenuhi di luar pondok atau D'Mart sebagai Kopontren.

Kedua, Pondok Pesantren El-Bayan berdiri diawali K.M. Syuhud pada tahun 1930 mendirikan Masjid sebagai rasa tanggung jawab terhadap kewajiban menyiarkan agama Islam di seluruh pelosok tanah air dalam perkembangannya berdirilah Pondok Pesantren Bendasari Majenang (PPBM). Tantangan globalisasi yang pesat seperti perkembangan media informasi, pergantian pimpinan dan pengasuh pondok pesantren, maka penting untuk lebih mengembangkan kombinasi sistem pendidikan non formal dan formal yang diberi nama Yayasan Pendidikan Agama Islam (YPAI) Pondok Pesantren ElBayan tahun 1971 dan terdaftar secara resmi pada tahun 1984. El-Bayan mempunyai visi membentuk manusia yang bertaqwa dan berakhlaqul karimah dengan misi membantu masyarakat dalam mewujudkan generasi Islam yang berhaluan ahlisunnah wal jamaah yang terampil dan mandiri.

Koperasi pondok pesantren (Kopontren) El Bayan berdiri sudah lama yaitu pada tahun 1977 sebagai bagian dari pendidikan dibidang usaha dan keterampilan yang pengelolaannya semua diserahkan kepada santri dengan bimbingan santri-santri senior.

Tantangan yang dihadapi Kopontren El Bayan adalah Koperasi dapat berkembang pesat dan telah memiliki badan hukum di El Bayan 2 sebagai lembaga pendidikan formal khususnya di Sekolah Menengah Kejuruan (SMK) ilmu komputer dan manajemen informatika, sedangkan di pondok pesantren El Bayan 1 yang merupakan lembaga pendidikan nonformal (santri pondok) belum memiliki kelembagaan koperasi yang formal dan kuat.

Pengurus Kopontren El Bayan 1 masih merintis untuk membentuk pengurus atau pengelola yang terstruktur, resmi dan memiliki kewenangan untuk mengembangkan koperasi, sehingga mengusulkan pada pimpinan pondok pesantren untuk menggunakan izin pendirian koperasi yang resmi dan sudah ada di El Bayan 2.

Pengurus Kopontren El Bayan 1 belum memiliki pemahaman dan kemampuan dalam manajemen perkoperasian seperti manajemen organisasi kepengurusan, keanggotaan, keuangan, dan pengembangan usaha. Kepengurusan masih dikelola oleh beberapa santri, tidak ada pergantian atau kaderisasi pengurus, dan santri pondok belum dilibatkan menjadi anggota koperasi, sehingga di koperasi El Bayan 1 menjadi pengurus dan anggota adalah sukarela. Unit usaha yang selama berkembang yaitu warung kelontongan untuk memenuhi kebutuhan harian santri dan masyarakat sekitar, sedangkan usaha lain yang masih dirintis seperti perbengkelan motor, isi ulang dan kemasan air minum membutuhkan peningkatan pengetahuan serta keterampilan dalam bentuk program pemberdayaan.

Koordinasi dan kerja sama masih belum terjalin dengan baik antara pengurus 


\section{Jurnal Pendidikan dan Pemberdayaan Masyarakat, 3 (2), November 2016 - 115 \\ Adhi Iman Sulaiman, M. Masrukin, C. Chusmeru, Sri Pangestuti}

koperasi di El Bayan 1 yang berbasis pendidikan pesantren pondok (non formal) dengan di El Bayan 2 yang berbasis pendidikan sekolah formal. Harapan yang besar dari pengurus Kopontren di El bayan 1 untuk bisa meniru, mendapat dukungan dan kerja sama dengan koperasi di El Bayan 2.

Koperasi pondok pesantren (Kopontren) di El Bayan 1 memiliki potensi untuk dapat berkembang santri sebagai pengurus Kopontren memiliki tekad dan semangat yang tigggi untuk mengembangkan koperasi menjadi lembaga usaha ekonomi bersama yang resmi dan didukung oleh semua pihak mulai dari pimpinan pondak pesantren dan para santri sebagai calon anggota serta kader pengurus.

Pondok di El Bayan 1 memiliki santri sekitar 570 orang yang dapat menjadi anggota dan kader pengurus Kopontren untuk memperkuat kelembagaan dan modal usaha.

Pengurus Kopontren memiliki semangat untuk mendapat program pemberdayaan seperti penyuluhan, pelatihan, pendampingan dan kemitraan untuk menambah pengetahuan, ketarampilan serta pengembangan usaha. Pengurus Kopontren memiliki unit usaha yang potensial untuk dikembangkan yaitu usaha isi ulang dan kemasan air minum, bengkel motor dan warung klontongan. Kemudian di dukung oleh akses yang mudah dan dekat dengan masyarakat, jalan besar menuju pasar dan pertokaan. Kawasan El Bayan 1 memiliki potensi luas lahan pertanian, peternakan dan perikanan yang dapat dijadikan unit usaha unggulan untuk menambah keterampilan pengurus dan anggota Kopontren dalam berwirausaha dan peningkatan kesejahteraan. Hal tersebut sesuai dengan Undang-Undang Nomor 17 Tahun 2012 tentang Koperasi, bahwa koperasi bertujuan meningkatkan kesejahteraan Anggota pada khususnya dan masyarakat pada umumnya, sekaligus sebagai bagian yang tidak terpisahkan dari tatanan perekonomian nasional yang demokratis dan berkeadilan.

Kopontren El Bayan 1 memiliki peluang untuk dapat menjalin hubungan baik meminta bantuan pelatihan dan pendampingan tentang pengelolaan Kopontren ke pengurus Kopontren El Bayan 2 yang telah maju dan berbadan hukum.

\section{Program Pemberdayaan bagi Koperasi Pondok Pesantren (Kopontren)}

Berdasarkan analisis realitas pada Koperasi Pondok Pesantren (Kopontren) di Pesantren Darussalam dan El Bayan 1, maka dapat dikonstruksi persamaan dan perbedaan untuk membuat program pemberdayaan. Persamaannya yaitu (1) Kopontren belum menjalankan manajemen kepengurusan, keanggoatan, keuangan dan pengembangan unit usaha, karena sedang memulai lagi pengembangan kepengurusan dan keanggotaan yang sempat terhambat oleh proses kaderisasi. (2) Permohonan perizinan secara informal dan formal ke pimpinan pondok pesantren sedang terus diusahakan khususnya tentang reorganisasi kelembagaan, kepengurusan, keanggoataan dan pengelolaan keuangan Kopontren. Selama ini pengelolaan dan kepengurusan Kopontren masih berdasarkan amanah dan keikhlasan sebagai tugas dari pimpinan pondok secara informal, sehingga belum dikelola secara formal dan membutuhkan sosialisasi atau penyuluhan dan pelatihan sebagai program pemberdayaan.

Pelaksanaan proses pemberdayaan melalui pelatihan dimulai dengan menyiapkan tim pengelola, membentuk kelompok usaha bersama guna mendapatkan legalitas (Saugi \& Sumarno 2015, p.236). Fasa (2014, p.2) menyatakan banyak pesantren yang telah berusaha mengembangkan aktivitas ekonomi produktif baik sebagai bagian dari aktivitas pendidikan para santri maupun sebagai aktivitas pesantren dengan masyarakat. (3) Keanggoatan Kopontren adalah seluruh santri yang ada di pondok pesantren, namun belum terdaftar lagi secara resmi dengan hak serta kewajibannya, seperti memiliki kartu anggota, memberikan simpanan wajib, simpanan pokok dan simpanan wajib serta memiliki hak peminjaman atau kredit barang. Aji (2011, p. 258) berpendapat koperasi pesantren memerlukan partisipasi, komitmen dan kemampuan inovasi anggota dan pengurus dengan memberi kesempatan pendidikan dan pelatihan, keterbukaan ide dan memperoeh kesempatan yang sama 


\section{Jurnal Pendidikan dan Pemberdayaan Masyarakat, 3 (2), November 2016 - 116}

Adhi Iman Sulaiman, M. Masrukin, C. Chusmeru, Sri Pangestuti

dalam akses informasi, meningkatkan kesejahteraan dan pelayanan pada anggota, anggota selalu dilibatkan dalam berbagai kebijakan strategis. Begitupun menurut Menurut Hermawan \& Suryono (2016, p. 104) meningkatkan partisipasi masyarakat dengan melibatkan masyarakat dalam setiap proses, mulai dari perencanaan, pelaksanaan, evaluasi sampai pada pengambilan manfaat. (4) Kopontren yang masih berjalan dan bisa dikembangkan adalah unit usaha usaha warung kelontongan yang menyediakan kebutuhan pokok harian santri tetapi masih skala kecil. Sehingga dapat ditingkatkan menjadi mini market yang lebih lengkap dan memiliki daya tarik serta melatih kemandirian santri baik ketika proses di pesantren maupun setelah lulus dari pesantren. Rangkuti (2011, p. 138) berpendapat bahwa pada dasarnya masyarakat berkoperasi adalah untuk memperoleh manfaat ekonomi dalam memenuhi kebutuhan pokok seharihari dan meningkatkan kesejahteraan. Widjajanti (2011, p.16) menyatakan kemandirian masyarakat merupakan suatu kondisi yang dialami oleh masyarakat yang ditandai dengan kemampuan memikirkan, memutuskan serta melakukan sesuatu yang dipandang tepat demi mencapai pemecahan masalah-masalah yang dihadapi dengan mempergunakan daya kemampuan yang dimiliki. (5) Kopontren memiliki modal awal dari pimpinan pondok dan pengurus, namun belum mendapatkan dari iuran anggota karena seluruh santri belum terdaftar menjadi anggota dengan hak dan kewajiban yang diberikan. Kepengurusan belum memiliki honor atau upah yang sesuai dan disepakati, sehingga sifatnya kesukarelaan atau berbasis keikhlasan karena diberikan amanah oleh pesantren. (6) Pengurus memiliki semangat yang tinggi untuk tetap melanjutkan dan memperjungkan Kopontren sebagai usaha bersama dan pendidikan berwirausaha. Pengurus membutuhkan penyuluhan, pelatihan dan pendampingan dalam pengelolaan Kopontren seperti dari perguruan tinggi, dinas koperasi pemerintah daerah dan lembaga koperasi yang telah sukses dengan materi seperti manajemen keorganisasian dan kepengurusan, manajemen keuangan dan pelaporan, manajemen keanggotan dan promosi serta manajemen pemasaran dan promosi serta kemitraan. Hidayat \& Soemarno (2000, p. 434) menyatakan aktifitas koperasi pondok pesantren perlu didukung oleh lembaga lain di pedesaan, yang mempunyai hubungan timbal balik antara koperasi dengan lembaga di sekitarnya. (7) Kopontren memiliki unit usaha yang potensial selain warung kelontongan yaitu usaha peternakan ikan, ayam, kambing dan itik. Usaha perbengkelan, jasa pengetikan, cetak kertas tugas sekolah dan photocopy. Letak pondok pesantren yang memiliki akses jalan dan dekat dengan perkotaan. Hal ini menjadi modal ekonomi yang dapat menciptakan peluang kerja dan pendapatan, serta modal sosial yaitu terjadi interaksi antara sesama santri dan masyarakat menjadi lebih kompak dan bekerja sama sebagai satu kesatuan. Ningsih (2016, p. 76) menyatakan peran koperasi pesantren sangatlah besar dalam pertumbuhan ekonomi peantren maupun warga sekitar yaitu dapat membuka peluang kerja, mengurangi pengangguran, dan meningkatkan kesajahteraan. Menurut Rifqi, Imron dan Mustiningsih (2016, p.687) pemberdayaan dalam bidang ekonomi dilakukan dengan membentuk kegiatan usaha seperti koperasi pesantren atas kerjasama pesantren, dan alumni. (8) Keterbatasan interaksi antara santri putra dan putri karena harus terpisah, dapat dibuat dua cabang Kopontren yang dapat memberdayakan dan melayani semuanya.

Perbedaan dari Kopontren Darussalam dan El Bayan adalah (1) Kopontren Darussalam Banyumas belum memiliki badan hukum izin pendirian, sehingga membutuhkan proses yang cukup panjang dalam merintisnya. Kopontren El Bayan sudah memiliki badan hukum izin pendirian koperasi, tetapi masih dimiliki atau bernaung di El Bayan 2 (SMK Komputer El Bayan) yang sudah memiliki dua koperasi berbadan hukum. Maka kondisinya sedang dalam proses negosiasi ke pimpinan pondok pesantren yayasan untuk diminta izin badan hukum yang sudah ada untuk dipergunakan bersama atau di alihkan ke Kopontren El Bayan 1. Sehingga Kopontren yang dimiliki harus diproses sampai memiliki badan hukum resmi. Sebagaimana menurut Menurut Undang-Undang Nomor 


\section{Jurnal Pendidikan dan Pemberdayaan Masyarakat, 3 (2), November 2016 - 117}

Adhi Iman Sulaiman, M. Masrukin, C. Chusmeru, Sri Pangestuti

17 tahun 2012 tentang Koperasi, bahwa yang dimaksud dengan koperasi adalah badan hukum yang didirikan oleh orang perseorangan atau badan hukum Koperasi,dengan pemisahan kekayaan para anggotanya sebagai modal untuk menjalankan usaha, yang memenuhiaspirasi dan kebutuhan bersama di bidang ekonomi, sosial, dan budaya sesuai dengan nilai dan prinsip koperasi. (2) Kopontren Darussalam hanya memiliki jenis usaha warung kelontongan dengan kapasitas sederhana dan baru akan berencana membuka jenis usaha jamur tiram, ternak ikan nila dan laundry itupun permodalamnya dari kompetsi hibah kreativitas mahasiswa di kampus. Kopontren El Bayan 1 sudah memiliki beberapa unit usaha seperti warung kelontongan dengan kapasitas lebih lengkap, perbengkelan motor, air minum isi ulang dan kemasan. Berencana akan membuka usaha lain seperti peternakan ikan dan kambing. Sehingga dengan potensi usaha ekonomi yang dimiliki Kopontren dapat dikembangkan dengan melakukan partisipasi semua pihak dan peberdayaan. Inovasi dalam pengembangan kelembagan sudah dilakukan khususnya promosi yang telah memanfaatkan media teknologi informasi dan komunikasi melalui media sosial email, blogspot, website dan alamat facebook. Hikmat (2010, p.4) menegaskan pemberdayaan dan partisipasi merupakan strategi yang sangat potensial dalam rangka meningkatkan ekonomi, sosial dan transformasi budaya. Menurut Widade (2011, p. 102) partisipasi yang besar dalam dunia digital social media merupakan potensi yang besar untuk mengubah peta pemasaran dengan mengurangi media konvensional (cetak dan udara) menjadi penguatan branding melalui kekuatan jejaring social media. (3) Kepengurusan Kopontren Darussalam dikelola oleh santri putri dan sekretariat pengurus masih belum lengkap. Kopontren El Bayan 1 kepengurusannya oleh santri putra, sekretariat sudah lengkap dengan peralatan administrasi.

Berdasarkan konstruksi persamaan dan perbedaan Kopontren, maka dapat dibuat program pemberdayaan yang disajikan pada Tabel 1 dan 2.

Tabel 1. Manajemen Kelembagaan dan Kepengurusan Kapontren

\begin{tabular}{|c|c|c|c|}
\hline Permasalahan & Potensi & Solusi & Model Pemberdayaan \\
\hline $\begin{array}{l}\text { Manajemen } \\
\text { Kelembagaan }\end{array}$ & & & \\
\hline $\begin{array}{l}\text { Koperasi belum } \\
\text { berbadan hukum }\end{array}$ & $\begin{array}{l}\text { Motivasi dan dedikasi } \\
\text { yang tinggi dari } \\
\text { pengurus }\end{array}$ & $\begin{array}{l}\text { Proses perizinan dapat } \\
\text { dirintis supaya koperasi } \\
\text { berbadan hukum }\end{array}$ & $\begin{array}{l}\text { Pendampingan sampai } \\
\text { memiliki izin yang } \\
\text { berbadan hukum }\end{array}$ \\
\hline $\begin{array}{l}\text { Kapontren sedang } \\
\text { dirintis kembali setelah } \\
\text { mengalami hambtan } \\
\text { kaderisasi }\end{array}$ & $\begin{array}{l}\text { Pengurus masih } \\
\text { memiliki semangat } \\
\text { untuk } \\
\text { mengembangkan } \\
\text { kapontren }\end{array}$ & $\begin{array}{l}\text { Pengurus memiliki } \\
\text { struktur kepengurusan, } \\
\text { agenda rapat } \\
\text { pertemuan, program } \\
\text { kerja (target), dan } \\
\text { AD/ART }\end{array}$ & $\begin{array}{l}\text { Sosialisasi/ penyuluhan } \\
\text { manajemen } \\
\text { keorganisasian, } \\
\text { kepengurusan dan } \\
\text { administrasi koperasi }\end{array}$ \\
\hline $\begin{array}{c}\text { Buku/kartu anggota } \\
\text { belum terdistribusikan } \\
\text { Manajemen } \\
\text { Pengurus dan } \\
\text { Keanggotaan }\end{array}$ & $\begin{array}{l}\text { Buku/kartu anggota } \\
\text { sudah tersedia }\end{array}$ & $\begin{array}{l}\text { Dibagikan ketika RAT } \\
\text { dan secara pro-aktif }\end{array}$ & $\begin{array}{l}\text { Pelatihan manajemen } \\
\text { administrasi dan } \\
\text { keanggotaan koperasi }\end{array}$ \\
\hline $\begin{array}{l}\text { Belum lengkap data } \\
\text { identitas anggota }\end{array}$ & $\begin{array}{l}\text { Data identitas anggota } \\
\text { ada di kapontren }\end{array}$ & $\begin{array}{l}\text { Dapat dilakukan } \\
\text { pendatan ulang } \\
\text { keanggotaan }\end{array}$ & \\
\hline $\begin{array}{l}\text { Pencatatan dan } \\
\text { dokumentasi masih } \\
\text { manual, belum } \\
\text { memanfaatkan fasilitas } \\
\text { komputer }\end{array}$ & $\begin{array}{l}\text { Tersedia komputer di } \\
\text { koperasi dan laptop } \\
\text { pengurus }\end{array}$ & $\begin{array}{l}\text { Peningkatan } \\
\text { kemampuan manajerial } \\
\text { dan kemmapuan } \\
\text { komputer bagi pengurus }\end{array}$ & $\begin{array}{l}\text { Pelatihan adminitrasi } \\
\text { dengan sistem } \\
\text { komputerisasi oleh } \\
\text { pengurus }\end{array}$ \\
\hline
\end{tabular}


Jurnal Pendidikan dan Pemberdayaan Masyarakat, 3 (2), November 2016 - 118

Adhi Iman Sulaiman, M. Masrukin, C. Chusmeru, Sri Pangestuti

Tabel 1. Manajemen Keanggotaan dan Permodalan Kapontren

\begin{tabular}{l} 
Permasalahan \\
\hline \multicolumn{1}{c}{ Keanggotaan } \\
Koperasi \\
Anggota belum \\
terdata secara \\
lengkap dan rinci \\
menurut \\
administrasi \\
perkoperasian
\end{tabular}

Anggota terpisah antara santri putra dan santri putri

\section{Permodalan dan Investasi}

Permodalan usaha dan untuk simpan pinjaman belum terpenuhi

Belum dapat memenuhi untuk pengembangan usaha seperti pupuk \& bibit pertanian, peternakan dan kelontongan

Program pemberdayaan difokuskan pada manajemen kelembagaan dan kepengurusan (Tabel 1) dan manajemen keanggotaan serta permodalan (Tabel 2) yang sangat penting dan menentukan untuk pengembangan Kopontren. Menurut Syahza (2011) kelembagaan membutuhkan terciptanya pelayanan yang baik terutama untuk memacu perekonomian seperti lembaga keuangan dan kelembagaan dirancang dalam jaringan kerja berdasarkan kemampuan dan profesionalisme yang dimiliki dari berbagai pelaku.

Kelembagaan menyangkut persoalan nilai, norma, etika, dan berbagai aturan tertulis. Aspek kajian lebih jauh adalah tentang sistem kepercayaan, moral, ide, gagasan, doktrin, keinginan, kebutuhan, dan orientasi (Syahyuti, 2005, p.87). Kelembagaan adalah suatu rules yang merupakan produk dari nilai, yang diharapkan terus berevolusi dan menjadi bagian dari budaya (culture) memiliki berdaya saing, berkerakyatan dan berkeadilan (Perhimpunan Ekonomi Pertanian Indonesia,2004, p. 47)

Berdasarkan hal tersebut membuat program pemberdayaan harus memperhatikan tahapan sebagai berikut yaitu (1) Mengidentifikasi masalah yang dihadapi yaitu masalah kelembagaan, keanggotaan dan permodalan, (2) Potensi yang dimiliki Kopontren. Hikmat (2010, p. 5) berpendapat 


\section{Jurnal Pendidikan dan Pemberdayaan Masyarakat, 3 (2), November 2016 - 119}

Adhi Iman Sulaiman, M. Masrukin, C. Chusmeru, Sri Pangestuti

proses pencapaian pemberdayaan melalui tahapan identifikasi kebutuhan, pilihan strategis, keputusan dan tindakan.

Potensi yang dapat dikembangkan di Kopontren yaitu sumber daya manusia (SDM) seperti pengurus dan anggota, sumber daya ekonomi atau unit usaha, sumber daya alam atau lingkungan dan sumber daya mental spiritual yang relevan dengan makna pendidikan serta pembentukan karakter yang baik atau akhlakulkarimah seperti semangat dan keikhlasan sebagai ibadah amaliyah, amanah artinya tangung jawab, jujur dan dapat dipercaya, ingin maju dengan berusaha (berikhtiar) dan bekerja sama (berjama'ah), hal ini merupakan kearifan lokal (local wisdom) pondok pesantren yang dapat dijadikan landasan pendidikan baik moral spiritual, ilmu pengetahuan dan kewirausahaan untuk kemandirian. Menurut Ife \& Toseriero (2008, p. 449) melestarikan dan menghargai tradisi budaya lokal bagian penting dalam bermasyarakat dan memperkuat identitasnya sebagai nilai serta peninggalan yang berharga (heritage). Hasim \& Remiswal (2009, p. 116) menyatakan kearifan lokal (local wisdom) adalah tata aturan masyarakat yang harmonis dengan alam sekitarnya dan komunitas memiliki peran yang penting. Menurut Saharuddin (2009, p.22) meluasnya pasar dan tuntutan produksi menjadikan kearifan lokal perlu didorong dan diberdayakan supaya lebih maju serta dapat menggunakan teknologi serta inovasi baru.

Relevansi program pemberdayaan untuk pengembangan menejemen kelembagaan, kepengurusan, keanggotaan dan modal perkoperasian yaitu koperasi dan pendidikan diwadahi oleh semangat kelembagaan yang sudah menjadi nilai, dan tradisi yang sudah tumbuh sejak lama. Tujuan dari pemberdayaan memiliki keterkaitan dengan pendidikan yaitu perencanaan secara sistematis, adanya penyadaran, transfer pengetahuan, pengalaman, perubahan pola pikir, sikap dan perilaku menjadi lebih baik, produktif serta berdaya atau memiliki kekuatan untuk berkembang dan mandiri. Mardikanto (2010, p. 125) menegaskan dalam pemberdayaan terdapat pengembangan kapasitas kualitas individu seperti pengetahuan dan kemampuan atau perbaikan pendidikan (better education and action), dan pengembangan kelembagaan (better institution) seperti perencanaan, pengorganisasian, pelaksanaan, pembiayaan dan pegendalian. Soleh (2014, p. 94-95) menyatakan tujuan pemberdayaan terjadinya proses perubahan mutu kehidupan yang lebih baik dan mandiri melalui tahapan yang sistematis diantaranya tahap penyadaran, identifikasi masalah dan penguatan kapasitas. Menurut Hermawan \& Suryono (2016,p.104) meningkatkan partisipasi masyarakat yaitu dengan berbasis komunitas, yang dimaksudkan tidak hanya pada individu tetapi juga komunitas dan kelompok-kelompok yang ada di dalam masyarakat.

\section{SIMPULAN DAN SARAN}

\section{Simpulan}

Pondok Pesantren (Ponpres) memiliki peran strategis dan penting yaitu sebagai lembaga pendidikan yang membentuk karakter dan perilaku yang agamis, bermoral dan spiritual, pendidikan ilmu pengetahuan, serta pendidikan sosial dan ekonomi untuk berinteraksi, berwirausaha dan mandiri dalam masyarakat seperti adanya Koperasi Pondok Pesantren (Kopontren). Kopontren Darussalam, Kembaran Kabupaten Banyumas dan El Bayan 1, Majenang Kabupaten Cilcacap memiliki (1) Tantangan untuk membenahi manajemen kepengurusan, keanggotaan dan keuangan dan serta pengembangan unit usaha. (2) Jumah santri yang banyak dapat menjadi anggota dan kader pengurus untuk memperkuat kelembagaan dan keuangan atau permodalan Kopontren. (3) Tekad dan semangat yang tinggi untuk mengembangkan kelompok usaha dan menjadi koperasi yang berbadan hukum sebagai bentuk pendidikan ekonomi yang menjadi bekal masa depan untuk berwirausaha, mandiri dan sejahtera. (4) Potensi yang besar dari warung kelontongan untuk dikembangkan menjadi lebih besar kapasitasnya dalam memenuhi kebutuhan pokok harian santri. (3) Lahan yang luas untuk unit usaha peternakan ayam, itik dan kambing serta perikanan. (4) Pengurus dan anggota Kopontren belum pernah mendapatkan program pem- 


\section{Jurnal Pendidikan dan Pemberdayaan Masyarakat, 3 (2), November 2016 - 120}

Adhi Iman Sulaiman, M. Masrukin, C. Chusmeru, Sri Pangestuti

berdayaan perkoperasian dan pengembangan unit usaha.

\section{Saran}

Kopontren Darussalam, Kembaran Kabupaten Banyumas dan El Bayan 1, Majenang Kabupaten Cilcacap membutuhkan (1) Dukungan dari pimpinan pondok pesantren untuk memberikan izin bagi reorganisasi kepengurusan, keanggotaan dan pengelolaan dan pengembangan unit usaha dan izin perkoperasian yang melibatkan seluruh santri sebagai kaderisasi Kopontren secara berkesinambungan. (2) Partisipasi semua pihak terutama para santri yang jumlahnya banyak untuk menjadi anggota dan kader pengurus yang potensial supaya keberlanjutan dan pengembangan lembaga Kopontren terus berkesinambungan. (3) Program pemberdayaan perkoperasian dari pemerintah daerah, perguruan tinggi dan lembaga sosial berupa sosialisasi, penyuluhan, pelatihan dan pendampingan tentang manajemen kepengurusan, keanggoataan, keuangan, mekanisme rapat pengurus dan anggota, serta pengembangan unit usaha dan kemitraan dengan pihak lain baik masyarakat sekitar, perguruan tinggi, pemerintah, dan swasta. (4) Kopontren harus mendapat dukungan dari semua pihak baik pimpinan Ponpres, pemerintah daerah, perguruan tinggi, lembaga sosial untuk menjadi pusat dan induk perekonomian serta pendidikan kewirausahaan bagi santri dan alumni, sehingga dapat berwirausaha atau membuka peluang kerja, mandiri dan menciptakan kesejahteraan bersama masyarakat di desa.

\section{DAFTAR PUSTAKA}

Ade, M. (2009). Ekonomi syariah peluang dan tantangan bagi ekonomi Indonesia. Al-Iqtishad, 1(1), 107-112

Aji, G. (2011). Faktor-faktor yang memenuhi kinerja koperasi pondok pesantren. Walisongo, 19(1), 231-260

Al-Hamdani, D. (2005). Pengembangan kepemimpinan transformasional. Bandung: Nuansa Aulia

Azyumardi, A. (1997). Pesantren, kontinuitas dan perubahan, dalam bilik-bilik pesantren : Sebuah potret perjalanan. Jakarta: Paramadina

Burhanuddin, R. (2006). Evaluasi program pendidikan dan latihan pada koperasi pondok pesantren. Jurnal Pengkajian Koperasi dan UKM, 2(1), 112

Chotimah, C. (2014). Pendidikan kewirausahaan di pondok pesantren sidogiri pasuruan. Inferensi, 8(1), 115136

Damanhuri, D. (2010). Ekonomi politik dan pembangunan: Teori, kritik, dan solusi bagi Indonesia dan negara sedang berkembang. Bogor: IPB Press

Daniar. (2013). Ekonomi kemandirian berbasis kopontren. Jurnal Ekonomi Islam, 1(2), 203-216

Fasa, M. I. (2014). Manajemen unit usaha pesantren: Studi kasus pondok modern Darussalam Gontor 1 Ponorogo Jawa Timur. Tesis. Universitas Islam Negeri Sunan Kalijaga, Yogyakarta

Hasim., \& Remiswal. (2009). Community development: berbasis ekosistem : sebuah alternatif pengembangan masyarakat. Jakarta: Diadit Media

Hermawan, Y., \& Suryono, Y. (2016). Partisipasi masyarakat dalam penyelenggaraan program-program pusat kegiatan belajar masyarakat Ngudi Kapinteran. Jurnal Pendidikan dan Pemberdayaan Masyarakat, 3(1), 97-108.

doi:http://dx.doi.org/10.21831/jppm.v 3i1.8111

Hidayat, H., \& Soemarno. (2000). Pemberdayaan koperasi pondok pesantren (Kopontren) melalui pengembangan usaha agribisnis jagung hibrida bisi-2. Agritek. 8(2), 427-435

Hikmat, H. (2010). Strategi pemberdayaan masyarakat. Bandung: Humaniora Utama Press

Ife, J., \& Tesoriero, F. (2008). Community development: Alternatif pengembangan masyarakat di era 
Jurnal Pendidikan dan Pemberdayaan Masyarakat, 3 (2), November 2016 - 121

Adhi Iman Sulaiman, M. Masrukin, C. Chusmeru, Sri Pangestuti

globalisasi. (Terjemahan Sastrawan, M., Nurul, .Y., \& Nursyahid, M). Yogyakarta: Pustaka Pelajar

Kusmanto, T.Y. (2014). Pengembangan ekonomi Islam berbasis kependudukan di perdesaan. Jurnal Ilmu Dakwah, 34(2), 219-235

Mardikanto, T. (2010). Konsep-konsep pemberdayaan masyarakat: acuan bagi aparat birokrasi, akademisi, praktisi, dan peminat atau pemerhati pemberdayaan masyarakat. Solo: UNS Peress

Muttaqin, A.i. (2014). Moderniasi Pesantren: Upaya rekonstruksi pendidikan Islam (Studi komparasi Studi Komparasi Pemikiran Abdurrahman Wahid dan Nurcholish Madjid). Tarbiyatuna, 7(2), 66-98

Nadzir, M. (2015). Membangun pemberdayaan ekonomi pesantren. Economica, 6(1), 37-56

Ningsih, L.A. (2016). Peran koperasi konsumsi pondok pesantren Raudhatul Ulum dalam pemberdayaan masyarakat setempat: Studi kasus di Masyarakat desa salatiga indralaya ogan ilir. Skripsi. Universitas Islam Negeri Raden Patah, Palembang

Peraturan Menteri Agama Republik Indonesia Nomor 18 Tahun 2014 tentang Satuan Pendidikan Muadalah pada Pondok Pesantren

Perhimpunan Ekonomi Pertanian Indonesia. (2004). Pembangunan perdesaan: Rekonstruksi kelembagaan ekonomi. Jakarta: Perhepi

Qomar, M. (2006). Pesantren dari transformasi metodologi menuju demokratisasi institusi. Jakarta: Erlangga

Rangkuti, F. (2011). SWOT balanced scorecard. Jakarta: PT Gramedia.

Rifki, A., Imron, A., \& Mustiningsih. (2016). Manajemen alumni di pondok pesantren modern dan salaf: Studi di pondok pesantren Nurul Jadid dan
Sidogiri. Jurnal Pendidikan, 1(4), 686691

Saharuddin. (2009). Pemberdayaan masyarakat miskin berbasis kearifan lokal. Sodality, 13(1), 17-44

Saugi, W., \& Sumarno, S. (2015). Pemberdayaan perempuan melalui pelatihan pengolahan bahan pangan lokal.Jurnal Pendidikan dan Pemberdayaan Masyarakat, 2(2), 226 - 238. doi:http://dx.doi.org/10.21831/jppm.v 2i2.6361

Soleh, C. (2014). Dialektika pembangunan dengan pemberdayaan. Bandung: Fokus Media

Suswanto, B., Handoko, W., \& Sabiq, A. (2013). Model community development sebagai strategi pemberdayaan berbasis kearifan lokal. Jurnal Review Politik, 3(2), 298312

Syahza, A. (2011). Percepatan ekonomi pedesaan melalui pembangunan perkebunan kelapa sawit. Publikasi Ilmiah UMS. Retrived from https://publikasiilmiah.ums.ac.id/ha ndle/11617/1325

Ubaidillah. 2010. Pandangan masyarakat terhadap pesantren : Studi kasus di desa tlogorejo kecamatan karangawen kabupaten demak. Skripsi. Universitas Agama Islam Negeri Walisongo, Semarang

Undang-Undang Nomor 17 tahun 2012 tentang Koperasi

Undang-Undang Nomor 20 tahun 2003 tentang Sistem Pendidikan Nasional

Widade, F. (2011). Pemanfaatan teknologi social media sebagai e-agribusiness dalam membangun. Prosiding Seminar Nasional Informatika Pertanian. Bandung: Himpunan Informatika Pertanian Indonesia.

Widjajanti, K. (2011). Model pemberdayaan masyarakat. Jurnal Ekonomi Pembangunan, 12(1), 15-27. 